\title{
TRACE METAL LEVELS IN VEHICLE AIR AND POLLEN FILTER DUSTS BY THE BCR EXTRACTION PROCEDURE
}

\author{
OCENA ZAWARTOŚCI METALI ŚLADOWYCH W POWIETRZU \\ SAMOCHODOWYM I W ODFILTROWANYCH PYŁACH \\ Z WYKORZYSTANIEM PROCEDURY EKSTRAKCJI BCR
}

\begin{abstract}
The availability of $\mathrm{Cd}, \mathrm{Co}, \mathrm{Cr}, \mathrm{Cu}, \mathrm{Mn}, \mathrm{Ni}, \mathrm{Pb}, \mathrm{Fe}$ and $\mathrm{Zn}$ of dust from vehicle air and pollen filters were investigated by four-step BCR (European Community Bureau of Reference) sequential extraction procedure. The acid-soluble, reducible, oxidizable, residual extracts were measured by inductively coupled plasma-optical emission spectrometry (ICP-OES). The results indicated that both of air and pollen filter dusts contained higher concentration of Fe. To estimate the accuracy of the method the standard reference material BCR 701 was used. The results for recovery all the elements were found in the range 95.4-101.3\%. The mean concentrations $[\mu \mathrm{g} / \mathrm{g}]$ of trace elements in dusts from air filters/pollen filters were: cadmium 16.72/17.56; cobalt 24.22/23.72; chromium 46.02/55.44; copper 44.92/37.67; iron 1868.03/1854.92; manganese 231.2/213.64; nickel 38.89/45.27; lead 60.99/67.17; zinc 199.58/201.25. The results obtained are in agreement with data reported in the literature.
\end{abstract}

Keywords: vehicle air filter, vehicle pollen filter, dust, trace metals

\section{Introduction}

Trace metals in the atmosphere may be present as dust particles [1]. This contamination is mostly caused by automobile engines and industry [2, 3]. Some of these trace metals important for enzymatic activities and the others were toxic when in excessive concentrations $[4,5]$. Toxic elements can lead to some diseases for human health and also have an impact on plant growth [6]. They can be transported to human bodies via air dusts and plants take up by foliage [7-9]. Many techniques are available to determine the atmospheric trace metal contamination. Coskun et al [10] reported moss biomonitoring technique based on microwave digestion and flame atomic absorption spectrometry to study atmospheric deposition of heavy metals.

Halek et al [11] used glass fiber filters for collecting the air dust samples for PM trace elements analysis by inductively coupled plasma based on microwave digestion. Wu et al [12] analyzed air dust samples by three stage sequential leaching procedure and inductively

\footnotetext{
${ }^{1}$ Department of Chemistry, Faculty of Arts and Science, Sakarya University, 54187 Sakarya, Turkey, phone +902642956059

*Corrensponding author: altundag@sakarya.edu.tr
} 
coupled plasma optical emission spectrometry. Quiterio et al [13] reported metals in airborne particulate matter by acid digestion and inductively coupled plasma atomic emission spectrometry.

Four step BCR sequential extraction procedures have been used to extract heavy metals in dust, sediments, soil etc. [14-16]. The chemical reagents provide selectively destroyed metal bounds with targeting carbonate bound metals, iron and manganese oxide associated metals, metals bound to sulphide and organic phases, and mineral phases respectively [17]. The four fractions representing water and acid soluble, easily reduced, oxidizable and residual fraction [18].

Sakarya is an industrial city of Turkey. Air trace metal content resulting from industrial activity may affect the urban areas. In this study trace metal components in dust from vehicle air and pollen filters were investigated. These filters are useful tools to collect air dust. Filters were collected from ten different vehicle used in Sakarya region in 2010-2011 time interval.

\section{Materials and methods}

All the samples were oven-dried at $105^{\circ} \mathrm{C}$ for $24 \mathrm{~h}$. Dried dust samples were passed through a sieve having a 200 mesh size. All the reagents used to prepare the extracting solutions were products of analytical grade quality (Merck, Germany). BCR 701 Standard Reference Material was used to certify the experimental results obtained and to evaluate the reliability of the method used [19]. ICP-OES (Spectro Analytical Instruments, Kleve, Germany), Nuve SL 350 model shaker, Nuve NF 400 model centrifuge and Schott CG 840 model $\mathrm{pH}$ meter were used throughout the experiments.

A four-step BCR sequential extraction procedure applied to dust samples is summarized below. $1.0 \mathrm{~g}$ dust was placed into $50 \mathrm{~cm}^{3}$ polypropylene centrifuge tubes. $40 \mathrm{~cm}^{3}$ of $0.11 \mathrm{M}$ of acetic acid was added to the tube which was then shaken for $16 \mathrm{~h}$ at of $22 \pm 5^{\circ} \mathrm{C}$ and a speed of $200 \mathrm{rpm}$. The extract was separated from the solid phase by centrifugation at $4000 \mathrm{rpm}$ for $15 \mathrm{~min}$. The supernatant liquid was stored at $4^{\circ} \mathrm{C}$ prior to analysis. $40 \mathrm{~cm}^{3}$ of $0.1 \mathrm{M}$ hydroxylamine hydrochloride (adjusted to $\mathrm{pH} 2$ with $2 \mathrm{M} \mathrm{HNO}_{3}$ ) was added to the residue from the bound to carbonates metals fraction (exchangeable and acid soluble). After shaking the mixture for $16 \mathrm{~h}$ at $22 \pm 3^{\circ} \mathrm{C}$ at a speed of $200 \mathrm{rpm}$, it was centrifuged for $15 \mathrm{~min}$ and then decanted into a beaker. $10 \mathrm{~cm}^{3}$ of $8.8 \mathrm{M} \mathrm{H}_{2} \mathrm{O}_{2}$ (pH of 2-3) was added carefully, in small aliquots, into the residue from bound to iron and manganese oxide metals fraction (reducible) in the centrifuge tube. The tube was covered loosely and digested at room temperature for $1 \mathrm{~h}$ with occasional shaking. The tube was then continuously digested for $1 \mathrm{~h}$ at $85 \pm 2^{\circ} \mathrm{C}$ in a water bath with occasional shaking for the first $30 \mathrm{~min}$ and the volume was then reduced to around $2-3 \mathrm{~cm}^{3}$ by further heating of the uncovered tube. Again, the covered tube was heated to $85 \pm 2^{\circ} \mathrm{C}$ and digested for $1 \mathrm{~h}$ before the volume in the uncovered tube was reduced almost to dryness after cooling, $25 \mathrm{~cm}^{3}$ of $1 \mathrm{M}$ ammonium acetate (adjusted to $\mathrm{pH} 2$ by adding of concentrated $\mathrm{HNO}_{3}$ ) was added to the residue and the tube was shaken for $16 \mathrm{~h}$ at room temperature. The extract was separated from the solid phase by centrifugation and separated from the solid phase by centrifugation and decantation as described above and stored at $4^{\circ} \mathrm{C}$. The residue (bound to mineral phases metals) from bound to sulfide and organic phases metals fraction (oxidizable) was digested in a mixture (3:1) of concentrated $\mathrm{HNO}_{3}$ and $\mathrm{HCl}$. The samples evaporated to dryness. 
Again, $10 \mathrm{~cm}^{3}$ aqua regia added and the same procedure was repeated. Solutions were filtered blue band filter paper. Filtrates was completed to $50 \mathrm{~cm}^{3}$ with nitric acid and stored at $4^{\circ} \mathrm{C}[7,20-23]$.

\section{Results and discussions}

In order to validation of the sequential extraction method results BCR-701 standard reference material was analyzed. The recoveries in each fraction are showed in Table 1 . The results were in agreement with the certified values for all metals. The recoveries were greater than $95.4 \%$ for bound to carbonates, $96.6 \%$ for bound to iron and manganese oxide and $96.4 \%$ for bound to sulfide and organic matters fractions.

Table 1

Results of extractable trace metals $[\mu \mathrm{g} / \mathrm{g}]$ on BCR 701 in comparison with certified values

\begin{tabular}{|c|c|c|c|}
\hline Cd & $\begin{array}{c}\text { Analyzed } \\
\text { value }\end{array}$ & $\begin{array}{c}\text { Certified } \\
\text { value }\end{array}$ & $\begin{array}{c}\text { Recovery } \\
{[\%]}\end{array}$ \\
\hline Acid soluble & $7.67 \pm 0.16$ & $7.34 \pm 0.35$ & 95.7 \\
\hline Oxidizable & $3.83 \pm 0.04$ & $3.77 \pm 0.28$ & 98.4 \\
\hline Reduced & $0.28 \pm 0.16$ & $0.27 \pm 0.06$ & 96.4 \\
\hline Cr & & & 97.4 \\
\hline Acid soluble & $2.32 \pm 0.26$ & $2.26 \pm 0.16$ & 99.3 \\
\hline Oxidizable & $46.0 \pm 0.2$ & $45.7 \pm 2.0$ & 98.6 \\
\hline Reduced & $145 \pm 4$ & $143 \pm 7$ & 95.4 \\
\hline Cu & & & 99.2 \\
\hline Acid soluble & $51.7 \pm 2.4$ & $49.3 \pm 1.7$ & 100.4 \\
\hline Oxidizable & $125 \pm 1$ & $124 \pm 3$ & 97.5 \\
\hline Reduced & $55.0 \pm 0.6$ & $55.2 \pm 4.0$ & 96.7 \\
\hline Ni & & & 101.3 \\
\hline Acid soluble & $15.8 \pm 1.3$ & $15.4 \pm 0.9$ & 96.4 \\
\hline Oxidizable & $27.5 \pm 1.5$ & $26.6 \pm 1.3$ & 98.4 \\
\hline Reduced & $15.1 \pm 2.1$ & $15.3 \pm 0.9$ & 96.9 \\
\hline Pb & & & 97.4 \\
\hline Acid soluble & $3.30 \pm 1.36$ & $3.18 \pm 0.21$ & \\
\hline Oxidizable & $128 \pm 3$ & $126 \pm 3$ & \\
\hline Reduced & $9.6 \pm 1.4$ & $9.3 \pm 2.0$ & \\
\hline Zn & & & $205 \pm 6$ \\
\hline Acid soluble & $206 \pm 2$ & $45.7 \pm 4.0$ & \\
\hline Oxidizable & $118 \pm 3$ & & \\
\hline Reduced & $46.9 \pm 1.3$ & & \\
\hline
\end{tabular}

Total metal contents of $\mathrm{Cd}, \mathrm{Co}, \mathrm{Cr}, \mathrm{Cu}, \mathrm{Mn}, \mathrm{Ni}, \mathrm{Pb}, \mathrm{Fe}$ and $\mathrm{Zn}$ in the dusts from vehicle air and pollen filters are shown in Table 2. The results show that Fe was most abundant metal in both of filters. The concentrations of metals in air filter dust samples were in the following order: $\mathrm{Fe}>\mathrm{Mn}>\mathrm{Zn}>\mathrm{Pb}>\mathrm{Cr}>\mathrm{Cu}>\mathrm{Ni}>\mathrm{Co}>\mathrm{Cd}$. These results were similar to levels found in pollen filter dust samples except $\mathrm{Ni}$. The concentration of $\mathrm{Cu}$ was lower than $\mathrm{Ni}$ in pollen filter dust samples and the concentrations of metals in the following order: $\mathrm{Fe}>\mathrm{Mn}>\mathrm{Zn}>\mathrm{Pb}>\mathrm{Cr}>\mathrm{Ni}>\mathrm{Cu}>\mathrm{Co}>\mathrm{Cd}$. There is a good agreement between this work and other similar studies reported in the literature. Highest concentrations of Fe also have been reported by Saracoglu et al [7] and Siddique et al [24]. The results 
obtained from air and pollen filter dust samples compared air dust, soil, sediments analysis works made in Turkey in Table 2. The concentration of $\mathrm{Cd}, \mathrm{Co}, \mathrm{Cr}, \mathrm{Cu}$ and $\mathrm{Pb}$ were found in vehicle air and pollen filter dust samples in this study higher than the other literature works except outdoor dust work made in Sakarya. Mn and Ni values in this study lower than sediment and outdoor dust works and $\mathrm{Zn}$ concentration lower than street and outdoor dust works made in Sakarya.

Table 2

Comparison of trace metals $[\mu \mathrm{g} / \mathrm{g}]$ concentration in vehicle air and pollen filter dusts to other studies made in Turkey

\begin{tabular}{|c|c|c|c|c|c|c|c|c|c|c|}
\hline Type & Cd & Co & $\mathrm{Cr}$ & $\mathrm{Cu}$ & Mn & $\mathbf{N i}$ & $\mathbf{P b}$ & $\mathbf{F e}$ & $\mathbf{Z n}$ & Reference \\
\hline $\begin{array}{l}\text { Vehicle air } \\
\text { filter dust }\end{array}$ & $\begin{array}{l}16.72 \\
\pm 0.05\end{array}$ & $\begin{array}{l}24.22 \\
\pm 0.13\end{array}$ & $\begin{array}{l}46.02 \\
\pm 0.06\end{array}$ & $\begin{array}{l}44.92 \\
\pm 0.12\end{array}$ & $\begin{array}{c}231.20 \\
\pm 0.25\end{array}$ & $\begin{array}{l}38.89 \\
\pm 0.12\end{array}$ & $\begin{array}{l}60.99 \\
\pm 0.12 \\
\end{array}$ & $\begin{array}{c}1868.03 \\
\pm 0.09\end{array}$ & $\begin{array}{c}199.58 \\
\pm 0.14\end{array}$ & This study \\
\hline \begin{tabular}{|c|} 
Vehicle \\
pollen filters \\
dust
\end{tabular} & $\begin{array}{l}17.56 \\
\pm 0.04\end{array}$ & $\begin{array}{l}23.72 \\
\pm 0.07\end{array}$ & $\begin{array}{l}55.44 \\
\pm 0.09\end{array}$ & $\begin{array}{l}37.67 \\
\pm 0.18\end{array}$ & $\begin{array}{c}213.64 \\
\pm 0.19\end{array}$ & $\begin{array}{l}45.27 \\
\pm 0.09\end{array}$ & $\begin{array}{l}67.17 \\
\pm 0.08\end{array}$ & $\begin{array}{c}1854.92 \\
\pm 0.21\end{array}$ & $\begin{array}{c}201.25 \\
\pm 0.21\end{array}$ & This study \\
\hline $\begin{array}{c}\text { Roadside } \\
\text { soil }\end{array}$ & - & - & - & - & - & 58.67 & 47.54 & - & - & [25] \\
\hline Street dust & 0.7 & - & 10.2 & 14.2 & - & 40.2 & 25.9 & - & 205.1 & [26] \\
\hline $\begin{array}{c}\text { River } \\
\text { sediment }\end{array}$ & $\begin{array}{c}2.62 \\
\pm 0.17 \\
\end{array}$ & $\begin{array}{l}21.21 \\
\pm 0.18 \\
\end{array}$ & $\begin{array}{l}36.96 \\
\pm 0.20 \\
\end{array}$ & $\begin{array}{l}37.54 \\
\pm 0.20 \\
\end{array}$ & $\begin{array}{c}772.00 \\
\pm 0.20\end{array}$ & $\begin{array}{l}82.96 \\
\pm 0.19\end{array}$ & $\begin{array}{l}41.31 \\
\pm 0.16 \\
\end{array}$ & $2023 \pm 0.21$ & $\begin{array}{l}76.67 \\
\pm 0.20 \\
\end{array}$ & [27] \\
\hline $\begin{array}{c}\text { Outdoor } \\
\text { dust }\end{array}$ & 21 & - & 340 & 1054 & - & 718 & 1185 & - & 1862 & [28] \\
\hline $\begin{array}{l}\text { Vehicle air } \\
\text { filter dust }\end{array}$ & 15.58 & - & - & 33.54 & 180 & - & - & 1625 & - & [7] \\
\hline $\begin{array}{c}\text { Lake } \\
\text { sediments }\end{array}$ & - & 3.0 & 11.5 & 19.2 & 99.8 & 19.2 & 8.05 & 3276 & 34.6 & [29] \\
\hline House dust & $1.4 \pm 0.1$ & $3.0 \pm 0.3$ & $\begin{array}{r}30.9 \\
\pm 2.4 \\
\end{array}$ & $62 \pm 5$ & $48.4 \pm 4$ & - & $\begin{array}{r}42.8 \\
\pm 3.7 \\
\end{array}$ & $1974 \pm 18$ & $225 \pm 20$ & [30] \\
\hline $\begin{array}{l}\text { Highway } \\
\text { soil }\end{array}$ & $\begin{array}{c}4.31 \\
\pm 4.32\end{array}$ & $\begin{array}{c}19.7 \\
\pm 11.8\end{array}$ & $\begin{array}{c}44.6 \\
\pm 42.4\end{array}$ & $\begin{array}{c}22.9 \\
\pm 18.1\end{array}$ & $555 \pm 340$ & $\begin{array}{c}132 \\
\pm 180\end{array}$ & $\begin{array}{c}31.2 \\
\pm 14.1\end{array}$ & $\begin{array}{c}2.554 \\
\pm 1.411 \\
(\%)\end{array}$ & $103 \pm 57$ & [31] \\
\hline Street dust & 2.53 & 16.5 & 29.0 & 36.9 & 237 & 44.9 & 74.8 & - & 112 & {$[32]$} \\
\hline \begin{tabular}{|c|} 
Faculty/ \\
House/ \\
Jean-market \\
dust \\
\end{tabular} & $\begin{array}{l}4.27 / \\
3.75 / \\
2.54\end{array}$ & - & $\begin{array}{l}38.7 / \\
53.5 / \\
53.5\end{array}$ & $\begin{array}{c}119.8 / \\
66.2 / \\
62.4\end{array}$ & - & $\begin{array}{l}64.8 / \\
37.8 / \\
97.8\end{array}$ & - & - & - & [33] \\
\hline
\end{tabular}

The mean levels and abundance percentages of the metal concentrations in air and pollen filters were shown in Table 3. The highest percentages of $\mathrm{Cd}$ in both of filters were found in the bound to carbonates fraction. The lowest abundance of $\mathrm{Cr}$ and $\mathrm{Fe}$ in air and pollen filters was found in this fraction. The results indicated that Mn was most abundant metal in bound to carbonate fractions. The highest release of $\mathrm{Mn}$ and $\mathrm{Zn}$ in air and pollen filters was found in this fraction. Relative abundance in each fraction of all elements in the air and pollen filter dust samples were shown in Figure 1. $\mathrm{Cr}, \mathrm{Fe}$ and $\mathrm{Pb}$ were presents at the higher level in the reducible fraction than exchangeable fraction. Fe was most abundant metal in bound to iron and manganese oxide fractions. $\mathrm{Cd}, \mathrm{Co}, \mathrm{Cu}, \mathrm{Mn}, \mathrm{Ni}$ and $\mathrm{Zn}$ were presents at the lower concentrations under reductive condition than acidic condition. The relative abundances were of all metals in the oxidizable fraction higher than reducible and exchangeable fractions except $\mathrm{Mn}$ and $\mathrm{Pb}$. The lowest releases of $\mathrm{Mn}$ in air and pollen filters were found in oxidizable fraction. The mean concentration of $\mathrm{Pb}$ in the oxidizable 
fraction was lower than reducible fraction and higher than exchangeable fraction in air filter dust samples. The lowest concentration of $\mathrm{Pb}$ was found in the oxidizable fraction in pollen filters. The highest release of $\mathrm{Cu}$ in pollen filters was found in oxidizable fraction and presents higher concentration level than exchangeable and reducible conditions in air filter dust samples. The mean $\mathrm{Cd}, \mathrm{Co}, \mathrm{Cr}, \mathrm{Ni}$ and $\mathrm{Zn}$ levels within the both of filters were higher than bound to carbonates and bound to iron and manganese oxide fractions. The highest concentrations of $\mathrm{Co}, \mathrm{Cr}, \mathrm{Fe}, \mathrm{Ni}$ and $\mathrm{Pb}$ in both of filter dust samples were found in residual fraction. The results indicated that $\mathrm{Fe}$ was most abundant metal in bound to sulphide and organic phases fractions. The lowest $\mathrm{Cd}$ levels were found in both of filters in residual fraction. The highest release of $\mathrm{Cu}$ in air filters was found in residual fraction and presents lower concentration level than oxidizable conditions in pollen filter dust samples. The lowest level of $\mathrm{Zn}$ in pollen filter dust samples were found in this fraction and the level in air filters higher than reducible fraction.

Table 3

Relative amount of metals extracted from vehicle air filters of the BCR sequential extraction

\begin{tabular}{|c|c|c|c|c|c|c|c|c|c|c|}
\hline $\begin{array}{l}\text { Ele- } \\
\text { ments }\end{array}$ & $\begin{array}{l}\text { Type of } \\
\text { filters }\end{array}$ & $\begin{array}{c}\text { Acid- } \\
\text { Soluble }^{\mathrm{a}}\end{array}$ & $\begin{array}{c}\text { Ratio } \\
{[\%]}\end{array}$ & $\begin{array}{l}\text { Redu- } \\
\text { cible }^{\text {a }}\end{array}$ & $\begin{array}{c}\text { Ratio } \\
{[\%]}\end{array}$ & $\begin{array}{c}\text { Oxidiz- } \\
\text { able }^{\mathrm{a}}\end{array}$ & $\begin{array}{c}\text { Ratio } \\
{[\%]}\end{array}$ & Residual $^{\mathbf{a}}$ & $\begin{array}{c}\text { Ratio } \\
{[\%]}\end{array}$ & Total $^{\text {b }}$ \\
\hline \multirow{2}{*}{$\mathrm{Cd}$} & Air Filter & $6.21 \pm 0.01$ & 37.14 & $3.73 \pm 0.06$ & 22.31 & $4.33 \pm 0.07$ & 25.90 & $2.45 \pm 0.04$ & 14.65 & $16.72 \pm 0.05$ \\
\hline & Pollen Filter & $7.54 \pm 0.06$ & 42.94 & $3.90 \pm 0.14$ & 22.21 & $4.07 \pm 0.10$ & 23.18 & $2.05 \pm 0.06$ & 11.67 & $17.56 \pm 0.04$ \\
\hline \multirow{2}{*}{ Co } & Air Filter & $5.24 \pm 0.03$ & 21.64 & $4.21 \pm 0.13$ & 17.38 & $6.40 \pm 0.05$ & 26.42 & $8.37 \pm 0.12$ & 34.56 & $24.22 \pm 0.13$ \\
\hline & Pollen Filter & $5.67 \pm 0.07$ & 23.90 & $4.17 \pm 0.01$ & 17.58 & $5.94 \pm 0.12$ & 25.04 & $7.94 \pm 0.05$ & 33.47 & $23.72 \pm 0.07$ \\
\hline \multirow[t]{2}{*}{$\mathrm{r}$} & Air Filter & $3.57 \pm 0.05$ & 7.76 & $5.64 \pm 0.09$ & 12.26 & \begin{tabular}{l|}
10.27 \\
\pm 0.09
\end{tabular} & 22.32 & $26.54 \pm 0.06$ & 57.67 & $46.02 \pm 0.06$ \\
\hline & Pollen Filter & $4.20 \pm 0.02$ & 7.58 & $5.50 \pm 0.10$ & 9.92 & $9.47 \pm 0.12$ & 17.08 & $36.27 \pm 0.09$ & 65.42 & $55.44 \pm 0.09$ \\
\hline \multirow{2}{*}{$\mathrm{Cu}$} & Air Filter & $7.51 \pm 0.14$ & 16.72 & $3.72 \pm 0.15$ & 8.28 & $\begin{array}{l}16.54 \\
\pm 0.16 \\
\end{array}$ & 36.82 & $17.15 \pm 0.24$ & 38.18 & $44.92 \pm 0.12$ \\
\hline & Pollen Filter & $9.12 \pm 0.09$ & 24.21 & $2.47 \pm 0.02$ & 6.56 & $\begin{array}{l}14.54 \\
\pm 0.20 \\
\end{array}$ & 38.60 & $11.54 \pm 0.21$ & 30.63 & $37.67 \pm 0.18$ \\
\hline \multirow{2}{*}{$\mathrm{Fe}$} & Air Filter & $34.58 \pm 0.07$ & 1.85 & $\begin{array}{c}218.94 \\
\pm 0.45 \\
\end{array}$ & 11.72 & $\begin{array}{c}487.23 \\
\pm 0.38 \\
\end{array}$ & 26.08 & $\begin{array}{c}1127.28 \\
\pm 0.12 \\
\end{array}$ & 60.35 & $\begin{array}{c}1868.03 \\
\pm 0.09 \\
\end{array}$ \\
\hline & Pollen Filter & $42.14 \pm 0.21$ & 2.27 & $\begin{array}{c}194.28 \\
\pm 0.36 \\
\end{array}$ & 10.47 & $\begin{array}{c}567.25 \\
\pm 0.15 \\
\end{array}$ & 30.58 & $\begin{array}{c}1051.25 \\
\pm 0.46\end{array}$ & 56.67 & $\begin{array}{c}1854.92 \\
\pm 0.21\end{array}$ \\
\hline \multirow{2}{*}{$\mathrm{Mn}$} & Air Filter & $86.71 \pm 0.25$ & 37.50 & $\begin{array}{l}52.17 \\
\pm 0.14\end{array}$ & 22.56 & $\begin{array}{l}36.76 \\
\pm 0.11\end{array}$ & 15.90 & $55.56 \pm 0.31$ & 24.03 & $\begin{array}{c}231.20 \\
\pm 0.25\end{array}$ \\
\hline & Pollen Filter & $91.54 \pm 0.16$ & 42.85 & $\begin{array}{l}47.27 \\
\pm 0.10 \\
\end{array}$ & 22.13 & $\begin{array}{l}28.49 \\
\pm 0.05 \\
\end{array}$ & 13.34 & $46.34 \pm 0.20$ & 21.69 & $\begin{array}{c}213.64 \\
\pm 0.19 \\
\end{array}$ \\
\hline & ter & $4.82 \pm 0.09$ & 12.39 & $3.27 \pm 0.06$ & 8.41 & $8.63 \pm 0.08$ & 22.19 & $22.17 \pm 0.15$ & 57.01 & $38.89 \pm 0.12$ \\
\hline & Pollen Filter & $5.94 \pm 0.15$ & 13.12 & $3.10 \pm 0.07$ & 6.85 & $7.69 \pm 0.11$ & 16.99 & $28.54 \pm 0.09$ & 63.04 & $45.27 \pm 0.09$ \\
\hline \multirow{2}{*}{$\mathrm{Pb}$} & \begin{tabular}{|l|} 
Air Filter \\
\end{tabular} & $5.40 \pm 0.13$ & 8.85 & $9.47 \pm 0.10$ & 15.53 & $7.61 \pm 0.14$ & 12.48 & $38.51 \pm 0.13$ & 63.14 & $60.99 \pm 0.12$ \\
\hline & Pollen Filter & $8.57 \pm 0.05$ & 12.76 & $9.50 \pm 0.16$ & 14.14 & $8.54 \pm 0.08$ & 12.71 & $40.56 \pm 0.05$ & 60.38 & $67.17 \pm 0.08$ \\
\hline \multirow{2}{*}{$\mathrm{Zn}$} & Air Filter & $64.32 \pm 0.21$ & 32.23 & $\begin{array}{l}37.91 \\
\pm 0.20 \\
\end{array}$ & 18.99 & $\begin{array}{l}52.64 \\
\pm 0.23 \\
\end{array}$ & 26.38 & $44.71 \pm 0.12$ & 22.40 & $\begin{array}{c}199.58 \\
\pm 0.14 \\
\end{array}$ \\
\hline & Pollen Filter & $71.76 \pm 0.20$ & 35.66 & $\begin{array}{l}42.50 \\
\pm 0.21 \\
\end{array}$ & 21.12 & $\begin{array}{l}47.27 \\
\pm 0.22 \\
\end{array}$ & 23.49 & $39.72 \pm 0.19$ & 19.74 & $\begin{array}{c}201.25 \\
\pm 0.21 \\
\end{array}$ \\
\hline
\end{tabular}

\footnotetext{
${ }^{\mathrm{a}}$ mean $[\mu \mathrm{g} / \mathrm{g}]$, standard deviation (SD)

${ }^{\mathrm{b}}$ total concentration of the four fraction $\pm \mathrm{SD}$
} 


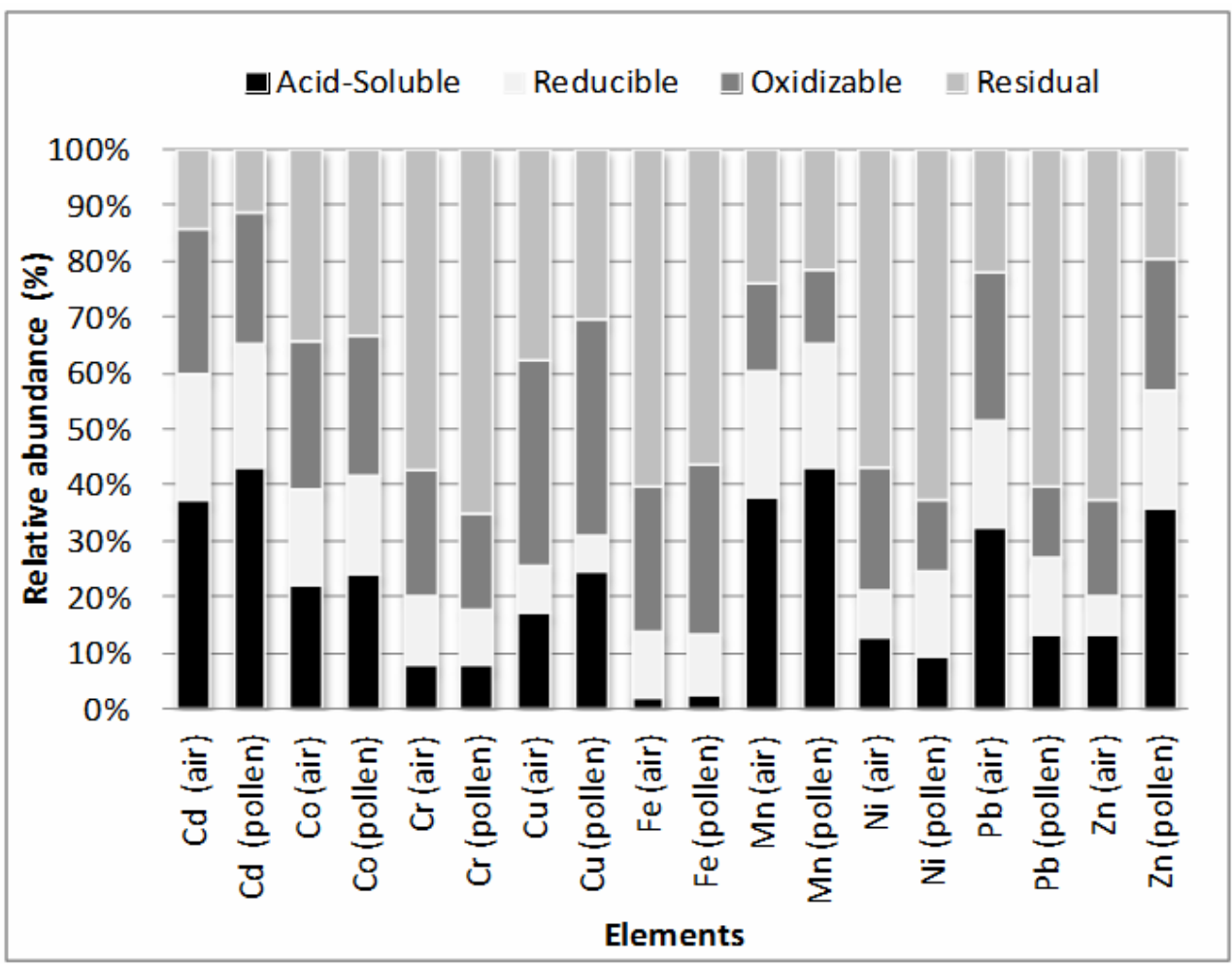

Fig. 1. Relative abundance in each fraction of all elements in the air and pollen filters dust samples

\section{Conclusion}

The highest percentages of $\mathrm{Cd}, \mathrm{Mn}$ and $\mathrm{Zn}$ were found in acid soluble fraction indicating that these metals were bound to carbonates and the mean concentrations $[\mu \mathrm{g} / \mathrm{g}]$ of these elements in dusts from air filters/pollen filters were: cadmium 6.21/7.54; manganese 86.71/91.54; zinc 64.32/71.76. Co (air filters/pollen filters: 34.6\%/33.5\%), Cr (air filters/pollen filters: 57.7\%/65.4\%), Fe (air filters/pollen filters: 60.4\%/56.7\%), Ni (air filters/pollen filters: $57.0 \% / 63.0 \%$ ) and $\mathrm{Pb}$ (air filters/pollen filters: $63.1 \% / 60.4 \%$ ) were mainly found in residual fraction which associated in the mineral structures. $\mathrm{Cu}$ was dominant in oxidizable and residual fractions indicating that bound to sulfide and organic matter. The calculated concentrations $[\mu \mathrm{g} / \mathrm{g}]$ of $\mathrm{Cu}$ in dusts from air filters/pollen filters were: $16.54 / 14.54$ in oxidizable and $17.15 / 11.54$ in residual fractions.

\section{Acknowledgments}

This work was financially supported by Sakarya University Commission of Scientific Research Projects (Project number: 2010.02.04.015). Thanks for the supply of air and pollen filters to Ozcan Demirkopru. 


\section{References}

[1] Larocque ACL, Rasmussen PE. An overview of trace metals in the environment, from mobilization to remediation. Environ Geol. 1998;33(2/3):85-89. DOI: 10.1007/s002540050227

[2] Cipurkovic A, Selimbasic V, Tanjic I, Micevic S, Pelemis D, Celikovic R. Heavy metals in sedimentary dust in the industrial city of Lukavac. Europ J Sci Res. 2011;54(3):347-362.

[3] Slavik R, Julinova M, Labudikova M. Screening of the spatial distribution of risk metals in topsoil from an industrial complex. Ecol Chem Eng S. 2012;19(1):259-272. DOI: 10.2478/v10216-011-0020.

[4] Ganatsas P, Tsakaldimi M, Zachariadis G. Effect of air traffic pollution on seed quality characteristics of Pinus brutia. Environ Exp Bot. 2011;74:157-161. DOI: 10.1016/j.envexpbot.2011.05.014.

[5] Rodrigues JL, Batista BL, Fillion M, Passos CJS, Mergler D. Trace element levels in whole blood of riparian villagers of the Brazilian Amazon. Sci Total Environ. 2009;407:4168-4173. DOI: 10.1016/j.scitotenv.2009.02.041.

[6] Altundag H, Tuzen M. Comparison of dry, wet and microwave digestion methods for the multi element determination in some dried fruit samples by ICP-OES. Food and Chemical Toxicology. 2011;49(11):2800-2807. DOI: 10.1016/j.fct.2011.07.064.

[7] Saracoglu S, Soylak M, Elci L. Extractable trace metals content of dust from vehicle air filters as determined by sequential extraction and flame atomic absorption spectrometry. J. AOAC Internat. 2009;92(4):1196-1202.

[8] Srinivas N, Rao RS, Kumar KS. Trace metal accumulation in vegetables grown in industrial and semi-urban areas-a case study. Appl Ecol Environ Res. 2009;7(2):131-139.

[9] Pieszko C, Sajdak M. Chemometric analysis of heavy metals coexistence in different plant matrices in the Upper Silesian industrial district. Ecol Chem Eng S. 2013;20(1):79-91. DOI: 10.2478/eces-2013-0006.

[10] Coşkun M, Frontasyeva MV, Steinnes E, Çotuk AY, Pavlov SS, Coşkun M, et al. Atmospheric deposition of heavy metals in thrace studied by analysis of moss (Hypnum Cupressiforme). Bull Environ Contamin Toxicol. 2005;74:201-209. DOI: 10.1007/s00128-004-0569-8.

[11] Halek F, Keyanpour-Rad M, Darbani RM, Kavousirahim A. Concentrations and source assessment of some atmospheric trace elements in northwestern region of Teheran, Iran. Bull Environ Contamin Toxicol. 2010;84:185-190. DOI: 10.1007/s00128-009-9902-6.

[12] Wu YF, Liu CQ, Tu CL. Atmospheric deposition of metals in TSP of Guiyang, PR China. Bull Environ Contamin Toxicol. 2008;80:465-468.

[13] Quiterio SL, Escaleira V, Sousa CRS, Maia LFPG, Arbilla G. Metals in airborne particulate matter in downtown Rio de Janeiro, Brazil. Bull Environ Contamin Toxicol. 2004;72:916-922. DOI: 10.1007/s00128-004-0331-2.

[14] Nemati K, Bakar NKA, Abas MRB, Sobhanzadeh E, Low KH. Comparison of unmodified and modified BCR sequential extraction schemes for the fractionation of heavy metals in shrimp aquaculture sludge from Selangor, Malaysia. Environ Monit Assess. 2011;176:313-320. DOI: 10.1007/s10661-010-1584-3.

[15] Tessier A, Campbell PGC, Bisson M. Sequential extraction procedure fort he speciation of particulate trace metals. Anal Chem. 1979;51(7):844-851.

[16] Rozanski S. Fractionation of selected heavy metals in agricultural soils. Ecol Chem Eng S. 2013;20(1):117-125. DOI: 10.2478/eces-2013-0009.

[17] Larner BL, Seen AJ, Townsend AT. Comparative study of optimised BCR sequential extraction scheme and acid leaching of elements in the certified reference material NIST 2711. Anal Chim Acta. 2006;556:444-449. DOI: 10.1016/j.aca.2005.09.058.

[18] Altundag H, Dundar MS, Doganci S, Celik M, Tuzen M. The use of a sequential extraction procedure for heavy metal analysis of house dusts by atomic absorption spectrometry. Journal of AOAC International 2013; 96(1):166-170. DOI: 10.5740/jaoacint.11-112.

[19] BCR 701, European Comission Joint Research Center. Institute for Reference Materials and Measurements IRMM. Geel, Belgium; 2001.

[20] Nemati K, Bakar NKA, Sobhanzadeh E, Abas MR. A modification of the BCR sequential extraction procedure to investigate the potential mobility of copper and zinc in shrimp aquaculture sludge. Microchem J. 2009;92:165-169. DOI: 10.1016/j.microc.2009.03.002.

[21] Cuong D, Obbard J. Metal speciation in coastal marine sediments from Singapore using a modified BCR-sequential extraction procedure. Appl Geochem. 2006;21:1335-1346. DOI: 10.1016/j.apgeochem.2006.05.001. 
[22] Sysalova J, Szakova J. Mobility assessment and validation of toxic elements in tunnel dust samples subway and road using sequential chemical extraction and ICP-OES/GF AAS measurements. Environ Res. 2005;101(3):287-293. DOI: http://dx.doi.org/10.1016/j.envres.2005.10.001.

[23] Pueyo M, Mateu J, Rigol A, Vidal M, Lopez-Sanchez JF, Rauret G. Use of the modified BCR three-step sequential extraction procedure for the study of trace element dynamics in contaminated soils. Environ Pollut. 2008;152(2):330-341. DOI: 10.1016/j.envpol.2007.06.020.

[24] Siddique N, Majid A, Tufail M. Elemental analysis of dust trapped in air conditioner filters for the assessment of Lahore city's air quality. J Radioanal Nucl Chem. 2011;290:691-699. DOI: 10.1007/s10967-011-1350-1.

[25] Sişman I, Imamoğlu M, Aydın AO. Determination of heavy metals in roadside soil from Sapanca area highway, Turkey. Int J Environ Pollut. 2002;17(4):306-311. DOI: 10.1504/IJEP.2002.000674.

[26] Dundar MS, Pala MF. Monitoring of lead, zinc, cadmium, nickel, chromium, copper in street dust samples in Adapazari, Turkey, after earthquake. Trace Elements and Electrolytes. 2003;20(2):104-107.

[27] Dundar MS, Altundag H, Eyupoglu V, Keskin CS, Tutunoglu C. Determination of heavy metals in lower Sakarya river sediments using a BCR-sequential extraction procedure. Environ Monit Assess. 2012;184:33-41. DOI: 10.1007/s10661-011-1944-7.

[28] Dundar MS, Deryaoglu N. Heavy metal determinations in outdoor atmospheric dust depositions. Fresenius Environ Bull. 2005;14(3):185-188.

[29] Tokalioğlu S, Kartal S, Elçi L. Determination of heavy metals and their speciation in lake sediments by flame atomic absorption spectrometry after a four-stage sequential extraction procedure. Anal Chem Acta. 2000;413:33-40.

[30] Narin I, Tüzen M, Soylak M. Comparison of sample preparation procedures for the determination of trace heavy metals in house dust, tobacco and tea samples by atomic absorption spectrometry. Ann di Chim. 2004;94(11):867-873. DOI: 10.1002/adic.200490107.

[31] Tokalıoglu S, Kartal S, Birol G. Application of a three-stage sequential extraction procedure for the determination of extractable metal contents in highway soils. Turk J Chem. 2003;27:333-346.

[32] Tokalığlu S, Kartal S, Birol G. Multivariate analysis of the data and speciation of heavy metals in street dust samples from the organized industrial district in Kayseri (Turkey). Atmos Environ. 2006;40:2797-2805. DOI: http://dx.doi.org/10.1016/J.atmosenv.2006.01.019.

[33] Soylak M, Uzek U, Narin I, Tüzen M, Turkoğlu O, Elçi L. Application of the sequential extraction procedure for dust samples from Kayseri-Turkey. Fresenius Environ Bull. 2004;13(5):454-457.

\title{
OCENA ZAWARTOŚCI METALI ŚLADOWYCH W POWIETRZU SAMOCHODOWYM I W ODFILTROWANYCH PYŁACH Z WYKORZYSTANIEM PROCEDURY EKSTRAKCJI BCR
}

\begin{abstract}
Abstrakt: Zbadano zawartość $\mathrm{Cd}, \mathrm{Co}, \mathrm{Cr}, \mathrm{Cu}, \mathrm{Mn}, \mathrm{Ni}, \mathrm{Pb}, \mathrm{Fe}$ i $\mathrm{Zn}$ w pyłach powietrza z pojazdów i w filtrach pyłowych za pomocą sekwencyjnej procedury ekstrakcji BCR (European Community Bureau of Reference). Skład ekstraktów zawierających substancje rozpuszczalne w kwasach, redukowalne i utlenialne był badany za pomocą metody indukcyjnie wzbudzonej plazmy sprzężonej z optyczną spektroskopią emisyjną (ICP-OES). Wyniki wskazują, że zarówno powietrze, jak i materiał z filtrów pyłowych zawierały zwiększone stężenia Fe. Do oszacowania dokładność metody wykorzystano standardowy materiał referencyjny BCR 701. Odzysk wszystkich pierwiastków mieścił się w zakresie 95,4-101,3\%. Średnie stężenia $[\mu \mathrm{g} / \mathrm{g}]$ pierwiastków śladowych $\mathrm{w}$ pyle z filtrów powietrza/filttrów pyłowych wynosiły dla kadmu 16,72/17,56; kobaltu 24,22/23,72; chromu 46,02/55,44; miedzi 44,92/37,67; żelaza 1868,03/1854,92; manganu 231,2/213,64; niklu 38,89/45,27; ołowiu 60,99/67,17; cynku 199,58/201,25. Uzyskane wyniki są zgodne z danymi literaturowymi.
\end{abstract}

Słowa kluczowe: samochodowy filtr powietrza, samochodowy filtr przeciwpyłowy, pył, metale śladowe 